\section{Rapid Development of Hypomagnesæmia in Lactating Cows given Artificial Rations Low in Magnesium}

THE most characteristic biochemical change associated with the disorder of cattle known variously as grass staggers, lactation or nutrition tetany and Hereford disease is a fall in the blood-serum magnesium concentration from a normal value within the range $2.0-3.5 \mathrm{mgm}$. $/ 100 \mathrm{ml}$. to one of $0.7 \mathrm{mgm}$. or less. The disorder has its highest incidence in milking cows in spring, shortly after a change from winter rations to the grazing of pasture, and under such conditions frequently the fall in serum magnesium concentration is rapid; in extreme cases serum magnesium values of less than $0.7 \mathrm{mgm} . / 100 \mathrm{ml}$. are observed within two days of the change of diet.

$\mathrm{We}^{1,2}$ have previously demonstrated with milking cows that a change from winter rations to grazing is commonly associated with a decrease in the net uptake of magnesium from the gut (magnesium in the feed less the magnesium excreted in the fæces), due to a reduction in the dietary intake of magnesium and, to a lesser extent, to a decrease in its availability to the animal: hypomagnesæmia occurs in animals in which the net uptake of magnesium from the gut is reduced to such an extent that it fails to meet the magnesium requirements of the animal for milk secretion, body retention and foetal growth, and in which, as a consequence, there is a drain on the small amount (2-3 gm.) of freely available magnesium in the blood serum and other extra-cellular fluids. The rapidity of development of hypomagnesæmia implies that the milking cow, during periods of acute magnesium deficiency, has little ability to mobilize any of the considerable amounts (100-200 gm.) of magnesium present in her soft tissues and bones.

Following the early investigations of Blaxter et al. ${ }^{3}$, I have made a number of attempts to develop for milking cows artificial diets low in magnesium with the object of determining the effect of a rapid reduction in dietary magnesium on serum magnesium concentration, and of ascertaining the minimum amount of dietary magnesium, in a suitable form, on which an animal can maintain normal serum magnesium concentrations. In such work, two main problems have to be overcome: the technical difficulties of preparing the necessarily large quantities of foodstuffs sufficiently low in magnesium, and the need to ensure that such foodstuffs are acceptable to the milking cow and do not lead to digestive disturbances and subsequent loss of appetite and milk yield. It seemed preferable in the first instance, therefore, to develop rations based largely on feedingstuffs in common use, but early experiments showed that the inclusion of large amounts of processed feeds low in magnesium, such as groats or flaked maize, effectively reduced magnesium intake but also improved markedly the assimilation of the magne. sium present in the roughage part of the ration. An artificial roughage low in magnesium was therefore prepared from paper pulp ${ }^{4}$. Daily rations of wheat straw (2 lb.), paper pulp treated with liquid invert sugar (6 lb.), flaked maize (14 lb.), blood meal (3 lb.), supplementary minerals and distilled water ad lib. have now been offered for periods of $2-3 \mathrm{wk}$. to four lactating cows, yielding 1-3 gallons per day, and though the rations supplied a total of only $2-3 \mathrm{gm}$. magnesium daily, the serum magnesium concentrations of the cows were little affected and remained within the range $2 \cdot 2-2 \cdot 7 \mathrm{mgm} . / 100 \mathrm{ml}$.
To determine the effect of a yet more extreme reduction in magnesium intake, a single animal was transferred, over three days, from the above ration to a highly artificial one, of wheat straw $(2 \mathrm{lb}$.), casein (3 lb.), starch (14 lb.) and supplementary minerals, which provided only $0.8 \mathrm{gm}$. magnesium daily. The full ration was consumed for two days only, but during this period the serum magnesium fell from $2 \cdot 2$ to $0.8 \mathrm{mgm} . / 100 \mathrm{ml}$. and an equally rapid recovery in concentration occurred with a return to the original ration.

An intermediate ration, of wheat straw (l lb.), paper pulp treated with liquid invert sugar (6 lb.), flaked maize (3 lb.), casein (2 lb.), starch (4 lb.) and supplementary minerals, supplying $1.5 \mathrm{gm}$. magnesium daily, has, with two cows to which it has been offered, proved acceptable and yet effective in causing rapid falls in serum magnesium concentration. The results obtained with one of these cows to which, in addition to the above ration, occasional supplements of magnesium were given are shown in Fig. 1.

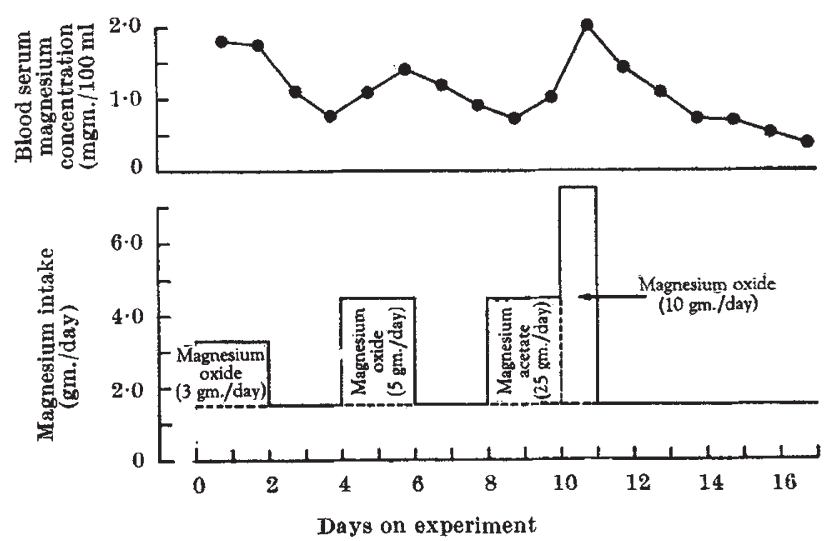

Fig. 1. Daily intakes of magnesium and the changes in the blood-serum magnesium concentration in a mature lactating cop given an artiffial ration, providing $1.5 \mathrm{gm}$. magnesium daily. and occasional supplements of magnesium. (The supplement of magnesium acetate given on days 9 and 10 was not readily eaten, due to its bitter taste, and was therefore replaced by magnesium oxide. On day 17 the cow refused her food and was removed from experiment: the symptoms of tetany that can occur at a serum magnesium concentration of $0.7 \mathrm{mgm} . / 100$ ml. or less were not observed)

These results for a mature lactating cow show that though the net requirement for magnesium is low, the animal nevertheless depends on a continuous dietary supply for the maintenance of normal serum magnesium concentrations and at critically low levels of magnesium intake the serum magnesium concentration is rapidly affected by small changes in the intake of magnesium. They demonstrate that the freely available body reserves of magnesium must be small in relation to the requirements of a milking animal and give support to our contention ${ }^{2}$ that hypomagnesæmia in cows at pasture is essentially nutritional in origin.

I am grateful to a number of colleagues, and in particular to Mr. V. W. Johnson, for help.

\section{J. A. F. Rook}

Chemistry Department,

National Institute for Research in Dairying, Shinfield, Berks.

${ }^{1}$ Rook, J. A. F., Balch, C. C., and Line, C., J. Agric. Sci., 51, 189 (1958).

2 Rook, J. A. F., and Balch, C. C., J. Agric. Sci.. 51, 199 (1958).

s Blaxter, K. L., and McGill, R. F., Vet. Rev, and Annot., 2, 35 (1956). - Rook, J. A. F., and Campling, R. C., J. Agric. Sci., 53, 330 (1959). 